\title{
The association between headache and low back pain: a systematic review
}

\author{
Arani Vivekanantham ${ }^{1,2,3^{*}} \mathbb{D}$, Claire Edwin ${ }^{1,2+}$, Tamar Pincus ${ }^{4}$, Manjit Matharu ${ }^{5}$, Helen Parsons ${ }^{6}$ and \\ Martin Underwood ${ }^{2,6}$
}

\begin{abstract}
Background: To systematically review studies quantifying the association between primary chronic headaches and persistent low back pain (LBP).

Main text: We searched five electronic databases. We included case-control, cross-sectional and cohort studies that included a headache and back pain free group, reporting on any association between persistent LBP and primary headache disorders. Methodological quality was assessed using Newcastle-Ottawa Scale. Our primary outcome was the association between primary headache disorders and persistent LBP. Our secondary outcomes were any associations between severity of LBP and severity of headache, and the relationship between specific headache sub-types classified as per International Classification of Headache Disorders (ICHD) criteria and persistent LBP. We included 14 studies. The sizes of the studies ranged from 88 participants to a large international study with 404, 206 participants. Odds ratios for the association were between 1.55 (95\% confidence interval (Cl) 1.13-2.11) and 8.00 (95\% Cl 5.3-12.1). Study heterogeneity meant statistical pooling was not possible. Only two studies presented data investigating persistent LBP and chronic headache disorders in accordance with ICDH criteria.
\end{abstract}

Conclusions: We identified a positive association between persistent LBP and primary headache disorders. The quality of the review findings is limited by diversity of populations, study designs and uncertainly about headache and LBP definitions.

Trial registration: PROSPERO 2018 CRD42018086557.

Keywords: Primary chronic headaches, Persistent low back pain, Epidemiology, Chronic pain syndromes

\section{Introduction}

Low back pain and headache are leading causes of disability worldwide $[1,2]$. Each headache disorder has specific diagnostic criteria [3]. The commonest types of headache are migraine, tension-type (both primary headaches) and medication overuse headache (a secondary headache) [4]. Migraine and tension-type headache featured in two of the eight causes of chronic disease and injury, each affecting more than $10 \%$ of the world's population [1]. Chronic headache is a severely disabling condition affecting around $3-4 \%$ of adults worldwide

\footnotetext{
* Correspondence: a.vivekanantham@doctors.org.uk

${ }^{\dagger}$ Arani Vivekanantham and Claire Edwin contributed equally as first authors on this manuscript.

1 University of Warwick, Coventry, UK

${ }^{2}$ University Hospitals Coventry and Warwickshire NHS Trust, Coventry, UK

Full list of author information is available at the end of the article
}

[5]. It is defined as a headache occurring on $\geq 15$ days per month for more than 3 months [3].

Low back pain has a high healthcare burden, and in the most recent global burden of disease study, both low back pain and migraine were featured in the five leading causes of years lived with disability [1]. Around $4 \%$ of the UK population take time off work because of low back pain, resulting in around 90 million working days lost and between 8 and 12 million General Practitioner (GP) consultations per year [6]. Chronic low back pain is defined as pain felt in the area between the bottom of the rib cage and the buttock creases for more than 3 months [7].

There is a considerable focus in headache management in achieving a precise diagnosis in line with the International Classification of Headache Disorders [3]. Once a diagnosis is identified, management is focused 
accordingly [3, 8]. In contrast once serious causes of low back pain are excluded (malignancy, vertebral fractures, inflammatory disorders or infection) non-specific low back pain is diagnosed. ${ }^{2,3}$,

People with persistent low back pain and people with chronic headache disorders are typically managed by clinicians from specific clinical specialities rather than experts in the management of chronic pain syndromes [9]. Whilst this approach may be appropriate for those living with one of these chronic conditions, it may be different if people have both. A previous systematic review of twin studies has identified a possible independent association between headache and low back pain [10]. People with both headache disorders and low back pain might constitute a neglected group that could have both conditions managed in combination rather than as separate entities. Here, we describe a systematic review of observational studies reporting the association between headaches (primary headaches, and chronic headaches) and persistent low back pain.

\section{Methods}

We sought to identify all case control, cohort and crosssectional studies reporting the relationship between primary headache disorders and persistent low back pain. We used a wide definition of headache disorders to reflect that exact headache type is often poorly defined and setting tight diagnostic criteria for study inclusion would exclude much of the available literature. Here, we use the term persistent to define low back pain duration rather than the term chronic [11]. This reflects that duration of low back pain is often poorly defined and using a strict definition for chronicity of back pain would exclude much of the available literature. For this review, we have reported the definitions of headache and low back pain used by the original authors of the included studies. This will allow the reader to interpret the findings cognisant of the definitions used.

The protocol for the review is registered on PROSPERO (PROSPERO 2018 CRD42018086557). This can be accessed via this link: http://www.crd.york.ac.uk/ PROSPERO/display_record.php?ID=CRD42018086557.

\section{Searches}

One reviewer (AV), with the assistance of an academic librarian, searched five electronic databases: Medline, Embase, Applied Social Sciences Index and Abstracts (ASSIA), PsychINFO and Web of Knowledge. These searches were supplemented by forward and backward citation tracking from included studies and relevant review papers. We excluded dissertations and conference proceedings. The electronic search terms included Medical Subject Headings (MeSH) headings, text words and truncation. Full details of the Medline search (as an exemplar) are available in online Appendix. Searches were run on 05/01/2018. A second search was run on 06/07/2018 to ensure recently published articles were included. The PRISMA 2009 checklist was used to ensure methodological quality [12]. The protocol for this systematic review was published on PROSPERO (registration number CRD42018086557).

\section{Primary outcome}

The association between chronic headache disorders and persistent low back pain.

\section{Secondary outcomes}

The relationship between severity of headache and low back pain.

The relationship between specific headache sub-types classified as per ICHD criteria and persistent low back pain [3].

We included any cross-sectional, cohort or casecontrol study, published in English. We sought to include studies reporting on the presence of headache, primary headache disorder, or medication overuse headache, with persistent low back pain with or without radicular pain. We had no restriction on age of participants. Studies were excluded if they did not compare participants to a control group 'no headache or no back pain groups'.

\section{Screening}

After removal of duplicates, two reviewers (AV and $\mathrm{CE})$ screened all abstracts and titles against the eligibility criteria using Covidence systematic review software (Veritas Health Innovation, Melbourne, Australia). Full texts of potential studies were then screened by the same reviewers. A further reviewer (MU) arbitrate any disagreement and agreed the final eligible studies.

Two reviewers (AV and CE) independently assessed the methodological quality of each study using the Newcastle-Ottawa Quality Assessment Scale (for cohort and adapted for cross-sectional studies) [13], MU adjudicated disagreements. Studies were not excluded on the basis of quality. The Newcastle-Ottawa Assessment of bias measures quality according to a starbased system; there is separate scoring system for cohort and cross-sectional studies. Each study is judged on three categories, selection of study groups, comparability of groups, and the ascertainment of either the exposure of interest in case-control studies or outcome of interest in cohort studies. Good quality studies receive a minimum of six stars [14]. Authors' conflicts of interests were noted. 


\section{Analysis}

The data on the association between headache and persistent low back pain were extracted independently by two reviewers (AV and $\mathrm{CE}$ ) and then compared for the final data extraction table which was checked by a statistical reviewer HP. We extracted the descriptions of headache and back pain phenotypes as reported by the original authors. Where appropriate original authors were contacted for clarification. Due to study heterogeneity, statistical pooling was not appropriate. We therefore used a narrative synthesis approach. We extracted odds ratios from papers that reported the presence or absence of headache with the presence or absence of persistent low back pain. Some papers presented odds ratios from a variety of different statistical models; in these cases, we chose the odds ratio from the multivariate adjusted model. In other cases, we calculated or corrected odds ratios from the data presented within the paper. Results presented are from published data only.

\section{Results}

\section{Searches}

We identified 5538 potentially relevant citations, which included 4410 unique citations, 4364 of which did not meet inclusion criteria. Overall, we identified 46 studies that warranted scrutiny of the full text, 15 of these were included in the review. Thirty-one studies were excluded because they did not include a headache and back pain free group, or did not report on any association between low back pain and headaches. We included 15 papers reporting on 14 studies (Fig. 1). Citation tracking did not yield any additional result.

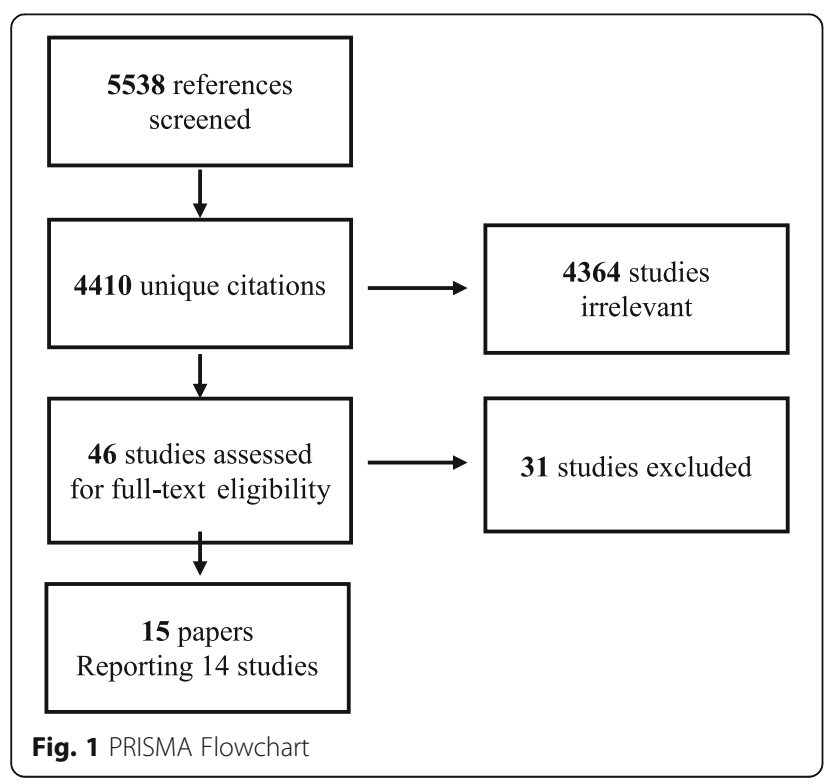

\section{Study characteristics}

Studies were heterogeneous, but a consistent positive association between headache and low back pain was found. This is consistent across countries, populations and study design but variable in magnitude. The odds ratios range from OR 1.72 (95\% CI 1.38-2.15) [15, 16] to 8 (95\% CI 5.3-12.1) [10].

Four studies were of children/adolescents (one cohort [17], three cross-sectional [18-20],) ten were adult studies (one cohort [21], four cross-sectional [10, 22-24], one cross-sectional older adult study [25], one cohort twin study [26], three cross-sectional twin studies) $[15,16,27,28]$ (Table 1).

Studies came from; Denmark (four studies) $[15,16,22$, $26,27]$, USA (2 studies) [18, 28], and one each from Germany [10], Iran [25], Norway [19], Switzerland [21], Tunisia [23], UK [17], and Qatar [24]. One large multinational study included participants from 29 countries from Europe, North America and Israel [20, 28].

Study size ranged from 88 participants [19] to a large international study with 404,206 participants [20]. Three studies had 8,000-10,000 participants. Overall, we include data on studies with 460,195 participants. Ages ranged from 9.8 years [20] to 102 years $[15,16]$ (Table 1 ).

\section{Methodological quality assessment}

All three cohort studies received seven stars or above $[17,21,26]$. Six cross-sectional studies were of good quality receiving seven stars or above $[10,15,16,18-20$, 22, 24] (Table 2).

For each included study, details of study funding source and study authors' conflicts of interests can be found in Additional file 1. Furthermore, the characteristics of excluded studies (for including the wrong outcome) can be found in Additional file 2.

\section{Definitions of headache and back pain}

Definitions of low back pain varied. Due to the nature of observational studies low back pain was self-reported but the detail asked of participants, and described by studies was variable (Table 1). Swain et al. [20], used a five point scale to report low back pain frequently in the past 6 months. Hartvigsen et al. [15, 16], asked several specific questions regarding low back pain ('have you during the past month suffered from back pain, acute low back pain or lumbago?') Few studies measured selfreported back pain with established questionnaires. Hestbaek et al. 2006 [26], measured low back pain with a Nordic questionnaire as did Sjolie et al. [19],. Bener et al. [24], used a variety of outcome measures including the Roland-Morris Disability Questionnaire [29], a widely used health status measure for low back pain. Jones et al. [17], provided an illustration of a shaded area of the lower back participants where participants may 
Table 1 Study Characteristics

\begin{tabular}{|c|c|c|c|c|c|c|c|}
\hline \multirow[t]{2}{*}{ Study ID } & \multirow[t]{2}{*}{ Country } & \multirow[t]{2}{*}{ Inclusion/Exclusion Criteria } & \multicolumn{2}{|l|}{ Definitions } & \multirow{2}{*}{$\begin{array}{l}\text { Size of } \\
\text { population (n) }\end{array}$} & \multirow[t]{2}{*}{ Age } & \multirow[t]{2}{*}{ Male (\%) } \\
\hline & & & Headache & Back pain & & & \\
\hline \multicolumn{8}{|l|}{ Cross-sectional Studies } \\
\hline \multicolumn{8}{|c|}{ Child and Adolescent Studies } \\
\hline $\begin{array}{l}\text { Ghandour et al., } \\
2004[15]\end{array}$ & USA & $\begin{array}{l}\text { Female adolescents (grades } \\
6-10 \text { ). }\end{array}$ & $\begin{array}{l}\text { Self-reported } \\
\text { headache. }\end{array}$ & $\begin{array}{l}\text { Self-reported } \\
\text { LBP }\end{array}$ & 8370 & $\begin{array}{l}12-16 \text { years } \\
\text { (range). }\end{array}$ & $0(0)$ \\
\hline $\begin{array}{l}\text { Sjolie et al., } 2002 \\
\text { [16] }\end{array}$ & Norway & Pupils aged $14-16$ years. & $\begin{array}{l}\text { Self-reported } \\
\text { weekly } \\
\text { headache. }\end{array}$ & $\begin{array}{l}\text { LBP, measured } \\
\text { by a Nordic } \\
\text { questionnaire. }\end{array}$ & 88 & $\begin{array}{l}14.1-16.1 \text { years } \\
\text { (range). }\end{array}$ & $50(57)$ \\
\hline $\begin{array}{l}\text { Swain et al., } 2014 \\
\text { [17] }\end{array}$ & $\begin{array}{l}\text { Europe, } \\
\text { America, } \\
\text { Israel) }\end{array}$ & Ages $11,13,15$ years. & $\begin{array}{l}\text { Self-reported } \\
\text { headache. }\end{array}$ & $\begin{array}{l}\text { Self-reported } \\
\text { LBP. }\end{array}$ & 404206 & $\begin{array}{l}\text { 9.8-17.3 years } \\
\text { (range). }\end{array}$ & $\begin{array}{l}197094 \\
(49)\end{array}$ \\
\hline \multicolumn{8}{|l|}{ Adult Studies } \\
\hline $\begin{array}{l}\text { Ashina et al. } 2018 \\
{[18]}\end{array}$ & Denmark & $\begin{array}{l}\text { Ages } 25-65 \text { years from } \\
\text { Danish Civil Registration } \\
\text { System }\end{array}$ & $\begin{array}{l}\text { Self-reported } \\
\text { headache. }\end{array}$ & $\begin{array}{l}\text { Self-reported } \\
\text { LBP. }\end{array}$ & 1300 & $\begin{array}{l}49.1,13.9 \\
\text { (mean, SD) }\end{array}$ & $\begin{array}{l}\text { Not } \\
\text { reported }\end{array}$ \\
\hline $\begin{array}{l}\text { Bejia et al. } 2005 \\
\text { [19] }\end{array}$ & Tunisia & $\begin{array}{l}\text { Staff at Fattouma Bourguiba } \\
\text { Teaching Hospital. }\end{array}$ & $\begin{array}{l}\text { Self-reported } \\
\text { migraine. }\end{array}$ & $\begin{array}{l}\text { Self-reported } \\
\text { LBP. }\end{array}$ & 350 & $\begin{array}{l}37,7.8 \text { (mean, } \\
\text { SD 7.88) } 18-60 \\
\text { (range). }\end{array}$ & $178(51)$ \\
\hline $\begin{array}{l}\text { Bener et al., } 2015 \\
\text { [20] }\end{array}$ & Qatar & $\begin{array}{l}\text { Ages } 15-65 \text { years from } \\
\text { primary care. }\end{array}$ & None given. & $\begin{array}{l}\text { Roland-Morris } \\
\text { Disability } \\
\text { Questionnaire. }\end{array}$ & 1829 & $\begin{array}{l}15-65 \text { years } \\
\text { (range). }\end{array}$ & $934(51)$ \\
\hline $\begin{array}{l}\text { Yoon et al., } 2013 \\
\text { [10] }\end{array}$ & Germany & Ages $18-65$ years. & $\begin{array}{l}\text { Self-reported } \\
\text { headache. }\end{array}$ & $\begin{array}{l}\text { Self-reported } \\
\text { LBP. }\end{array}$ & 9944 & $\begin{array}{l}43,13.1 \text { (mean, } \\
\text { SD). }\end{array}$ & $4703(47)$ \\
\hline \multicolumn{8}{|l|}{ Older Adult Studies } \\
\hline $\begin{array}{l}\text { Ahangar et al. } \\
2016 \text { [21] }\end{array}$ & Iran & $\begin{array}{l}\text { Ages } \geq 60 \text { years from } \\
\text { Amirkola town. }\end{array}$ & $\begin{array}{l}\text { Self-reported } \\
\text { headache. }\end{array}$ & $\begin{array}{l}\text { Self-reported } \\
\text { LBP. }\end{array}$ & 1499 & $\begin{array}{l}\text { Frequency of } \\
\text { age ranges: } \\
\text { 60-64 (36.9\%) } \\
65-69(30 \%) \\
70-74(17.6 \%) \\
75-79(15 \%) \\
80-84(6 \%) \\
85-99(3 \%)\end{array}$ & $832(55)$ \\
\hline \multicolumn{8}{|l|}{ Twin Studies } \\
\hline $\begin{array}{l}\text { Hartvigsen et al., } \\
2004 \text { [22] } \\
\text { (Hartvigsen et al., } \\
2003 \text { [23]) }\end{array}$ & Denmark & $\begin{array}{l}\text { Danish twin study.Twins aged } \\
\geq 75 \text { years. }\end{array}$ & $\begin{array}{l}\text { Self-reported } \\
\text { migraine. }\end{array}$ & $\begin{array}{l}\text { Self-reported } \\
\text { LBP. }\end{array}$ & 4484 & $\begin{array}{l}\text { 70-102 years } \\
\text { (range). }\end{array}$ & N/A \\
\hline $\begin{array}{l}\text { Hestbaek et al., } 2004 \\
\text { [24] }\end{array}$ & Denmark & $\begin{array}{l}\text { Danish twin study. Twin aged } \\
12-22 \text { years }\end{array}$ & $\begin{array}{l}\text { Self-reported } \\
\text { headache. }\end{array}$ & $\begin{array}{l}\text { Self-reported } \\
\text { LBP.Self- }\end{array}$ & 9567 & $\begin{array}{l}\text { Frequency of } \\
\text { age ranges: } \\
12-13(n= \\
1492) . \\
14-16(n= \\
2533) . \\
17-19(n= \\
2668) . \\
20-22(n= \\
2874) .\end{array}$ & $4580(49)$ \\
\hline Schur et al., 2007 [25] & USA & $\begin{array}{l}\text { Twins from the University of } \\
\text { Washington Twin Registry } \\
\text { (UWTR). }\end{array}$ & $\begin{array}{l}\text { Self-reported a } \\
\text { doctor's } \\
\text { diagnosis } \\
\text { headache. }\end{array}$ & $\begin{array}{l}\text { Self-reported a } \\
\text { doctor's } \\
\text { diagnosis LBP. }\end{array}$ & 3982 & $\begin{array}{l}32.4,14.7 \\
\text { (mean, SD) }\end{array}$ & $1536(39)$ \\
\hline \multicolumn{8}{|l|}{ Cohort Studies } \\
\hline \multicolumn{8}{|c|}{ Child and Adolescent Studies } \\
\hline $\begin{array}{l}\text { Jones et al., } 2003 \\
\text { [26] }\end{array}$ & UK & $\begin{array}{l}\text { Ages } 11 \text { to } 14 \text { years, from } 39 \\
\text { secondary schools. }\end{array}$ & $\begin{array}{l}\text { Self-reported } \\
\text { headache. }\end{array}$ & $\begin{array}{l}\text { Self-reported } \\
\text { LBP. }\end{array}$ & 933 & $\begin{array}{l}11-14 \text { years } \\
\text { (range). }\end{array}$ & $\begin{array}{l}\text { Not } \\
\text { reported. }\end{array}$ \\
\hline \multicolumn{8}{|l|}{ Adult Studies } \\
\hline Angst et al., 2017 & Switzerland & A representative age cohort & Self-reported & Self-reported & 4547 & $27 / 28$ in 1986 & 1071 \\
\hline
\end{tabular}


Table 1 Study Characteristics (Continued)

\begin{tabular}{|c|c|c|c|c|c|c|c|}
\hline \multirow[t]{2}{*}{ Study ID } & \multirow[t]{2}{*}{ Country } & \multirow[t]{2}{*}{ Inclusion/Exclusion Criteria } & \multicolumn{2}{|l|}{ Definitions } & \multirow{2}{*}{$\begin{array}{l}\text { Size of } \\
\text { population (n) }\end{array}$} & \multirow[t]{2}{*}{ Age } & \multirow[t]{2}{*}{ Male (\%) } \\
\hline & & & Headache & Back pain & & & \\
\hline [27] & & $\begin{array}{l}\text { of the general population of } \\
\text { the canton of Zurich. }\end{array}$ & headache. & LBP. & & $\begin{array}{l}\text { then } 49 / 50 \text { in } \\
2008 .\end{array}$ & \\
\hline \multicolumn{8}{|l|}{ Twin Studies } \\
\hline $\begin{array}{l}\text { Hestbaek et al., } \\
2006[28]\end{array}$ & Denmark & $\begin{array}{l}\text { Danish twins born between: } \\
\text { 1972-1982. Aged 12-22 years }\end{array}$ & $\begin{array}{l}\text { Self-reported } \\
\text { headache. }\end{array}$ & $\begin{array}{l}\text { Nordic Back } \\
\text { pain } \\
\text { questionnaire. }\end{array}$ & $\begin{array}{l}\text { Baseline: } 9,600 \\
(84 \%) \text {. Follow } \\
\text { up: } 6554 .\end{array}$ & $\begin{array}{l}17.27 \text { (11-22) } \\
\text { (mean, } \\
\text { baseline). } \\
17.38 \text { (11-22) } \\
\text { (mean, follow- } \\
\text { up). }\end{array}$ & $\begin{array}{l}\text { Baseline: } \\
4654 \\
(48 \%) . \\
\text { Follow up } \\
2868 \\
\text { (44\%). }\end{array}$ \\
\hline
\end{tabular}

1 LBP, Low back pain

have expected to experience low back pain in the past month. Angst et al. [21], distinguished between lumbar back pain versus cervical pain [21].

Persistency of low back pain was described infrequently. Chronic low back pain was defined by pain in the low part of the back and thigh pain radiating to above the knee lasting over 3 months by Bejia et al. [23] Hestbaek et al. 2006 [26], defined persistent low back pain being longer than 30 days in the past year, Yoon et al. asked for self-reported low back pain more than 15 days per month [10]. Ashina measured low back pain by self-reported frequency in the last year [22].

Like low back pain, there were varying definitions of headache, and chronic headache. Only the two studies by Ashina et al. [22], and Yoon et al. [10] used the ICHD (2nd edition) [30], now superseded by a third edition [3]. Yoon et al. also used a validated headache-screening questionnaire [10, 31]. Six studies specified that migraine or headache was self-reported [15, 16, 18-20, 23, 25]. Bener et al. [24], and Jones et al. [17], provided no definition, and Angst et al. [21] reported on participants reporting migraine or headache.

Hestbaek et al. [26], analysed participants according to any positive answers to headache regardless of aetiology (migraine, headache with nausea, headache with photophobia/phonophobia, severe ocular pain). Schur et al. [28] asked if participants had a doctor's diagnosis of headache, the authors here also explained why they used a self-reported method rather than diagnostic criteria, as validated measures were too lengthy and diagnostic criteria were not agreed upon. Hartvigsen et al. $[15,16]$ asked participants in a survey whether a physician had ever told them they suffered from various diseases (outcome reported as migraine headache in results), answers were taken as valid if participants confirmed that a diagnosis was made by a physician. Therefore, whether participants are truly reporting migraine or another type of headache is unclear $[15,16]$.

Three studies involved face-to-face interviews within the sample. Ahangar et al. [25] used a mixture of questionnaires and in-person interviews to collect data from elderly people in the town of Amirkola, Iran. Bener et al. [24] used trained nurses to interview patients and complete questionnaires. Angst et al. [21] used a stratified subsamples of the original sample for face-to-face interviews, two-thirds of those participants scoring high risk for psychopathological syndromes according to the Symptom Checklist-90-R [32].

No studies reported on the severity of headache and severity of low back pain.

\section{Relationship between specific headache types and persistent low back pain}

Table 3 summarises the results of the included studies. Ashina et al. [22] found 649/796 (81.5\% of their participants had lifetime prevalence of low back pain); 321/ $796(40.3 \%)$ of their participants had primary headache (migraine and/or frequent episodic tension type headache or chronic tension type headache). Of these 475/ 796 (59.7\%) reported infrequent episodic tension type headache or no headache categorised as no headache in the past year; 281/796 (35.3\%) had episodic headache, $80 / 796$ (10.1\%) had pure migraine, $138 / 796$ (17.3\% had pure tension type headache, and 103/796 (12.9\%) had coexistent migraine and tension-type headache. No case of chronic migraine was identified in the study. Ashina et al. [22] noted a positive correlation between the number of days with tension type headache or migraine and number of days with low back pain in the past year $(r=0.25, p<0.001, r=0.16, p<0.001$, respectively). The lifetime relative frequency of low back pain was higher in those with primary headache migraine and or tension type headache than those without headache $(87.2$ versus $77.7 \%)(p=0.001)$. The adjusted odds ratio for primary headache (migraine and or frequent tension type headache or chronic tension type headache) and low back pain was OR 1.7 (95\% CI 1.2-2.5).

Yoon et al. [10], identified those affected by chronic low back pain and primary headache disorders. The outcome variable of low back pain was defined as presence of frequent low back pain (yes vs. no), defined as selfreported low back pain occurring on more than or equal 


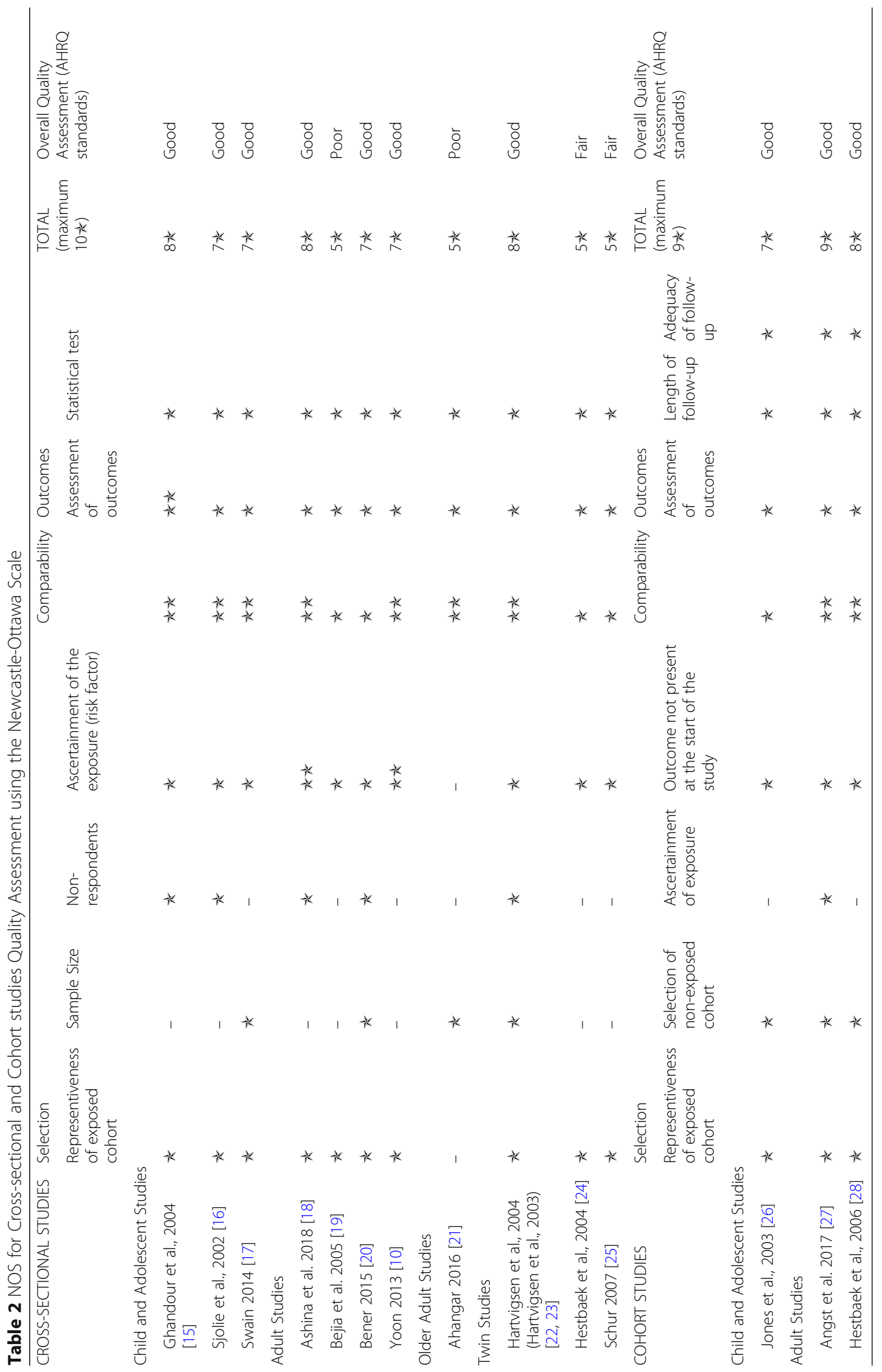




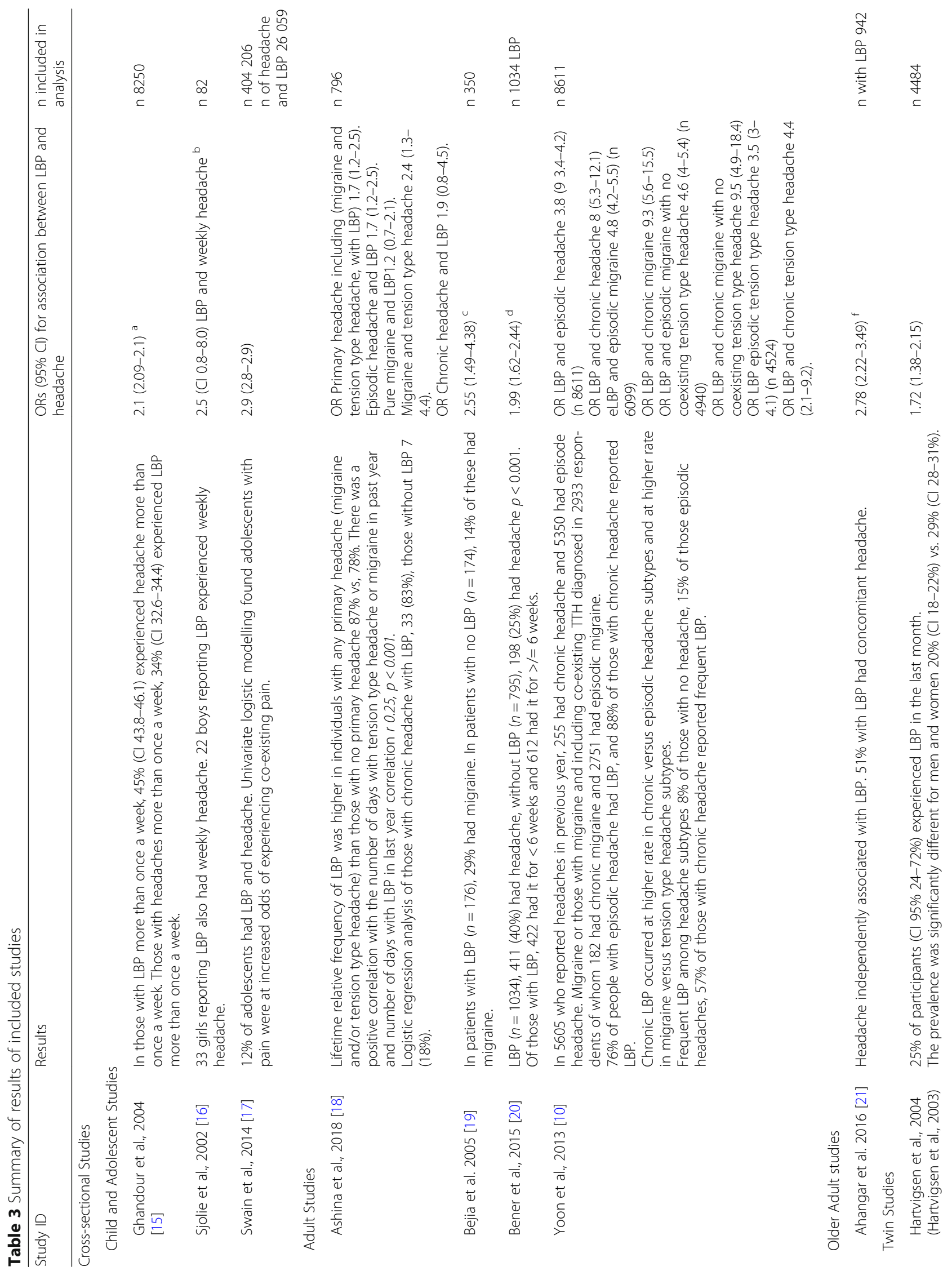




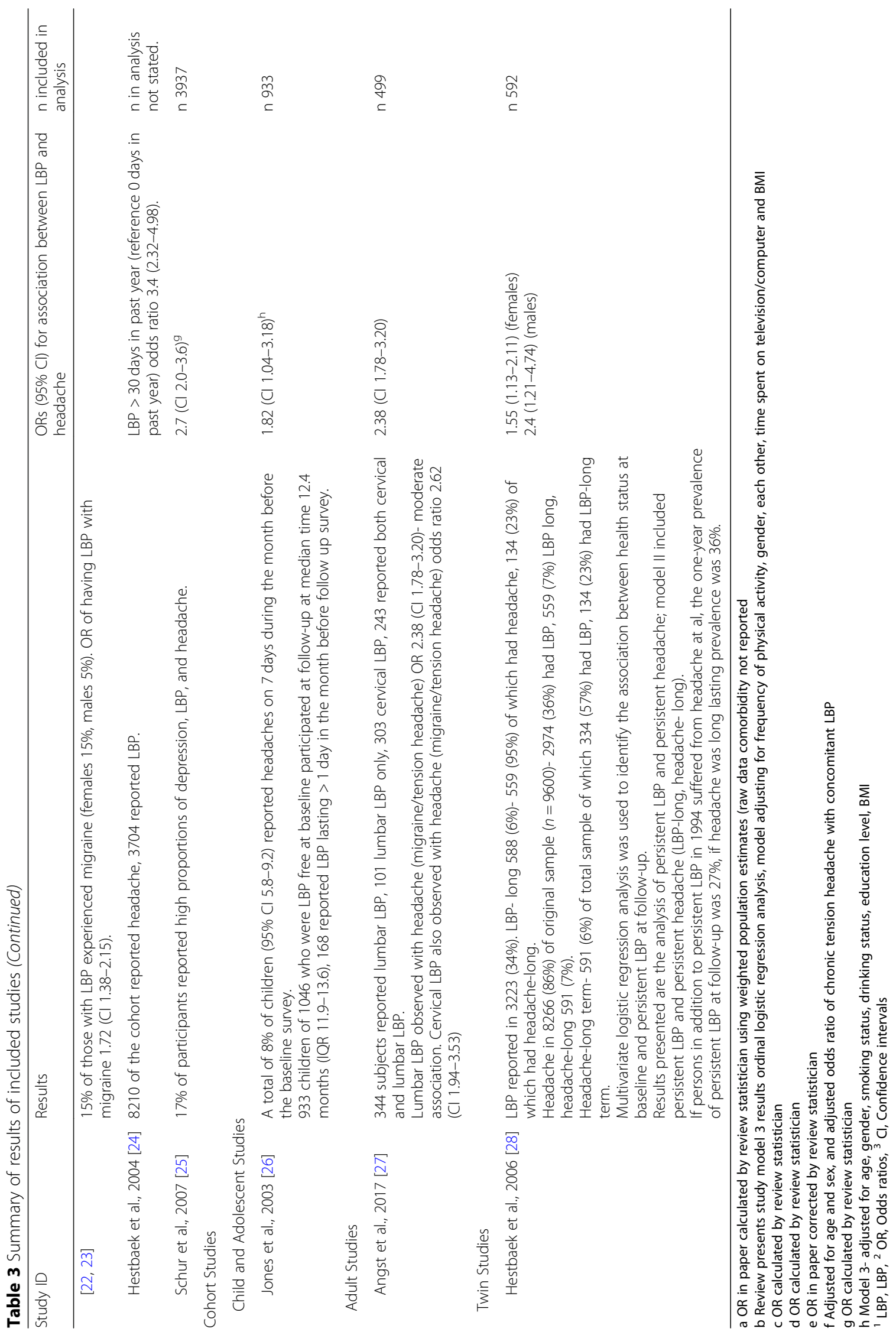


to 15 days per month. We present their multivariate analysis results (adjusted for age, gender, smoking status, drinking status, education level, BMI).

The association between migraine and low back pain was OR 1.2 (95\% CI 0.7-2.1) (Ashina et al.) [22], and frequent low back pain and episodic migraine (no coexisting tension-type headache) OR 4.6 (95\% CI 4.0-5.4)(Yoon et al) [10]. The association between episodic headache and low back pain was OR 1.7 (95\% CI 1.2-2.5) (Ashina et al.) [22] and frequent low back pain and episodic headache OR 3.8 (95\% CI 3.4-4.2) (Yoon et al) [10]. Associations between tension-type headache and low back pain were as follows; pure tension-type headache and low back pain OR 1.9 (95\% CI 1.2-3.1) (Ashina et al.) [22] and episodic tension-type headache OR 3.5 (95\% CI 3.0-4.1) (Yoon et al) [10].

\section{Combining migraine and tension type headache disorders and experience of low back pain}

Ashina et al. [22] found an OR 2.4 (95\% CI 1.3-4.4), and Yoon et al. [10] found an OR 4.8 (95\% 4.2-5.5) between frequent low back pain and episodic migraine with coexisting tension-type headache.

\section{Chronic headache and low back pain}

Ashina et al. [22] found 40 individuals that reported chronic headache. In their analysis of chronic headache and low back pain the adjusted odds ratio was 1.9 (95\% CI 0.8-4.5). Low back pain was used in analysis if it had been reported occurring at least 1 day in the past year.

Yoon et al. [10], found an odds ratio of chronic low back pain and chronic headache of 8 (95\% CI 5.3-12.1); low back pain and chronic migraine with coexisting tension type headache OR 9.3 (95\% CI 5.6-15.5); low back pain with chronic migraine (no coexisting tension type headache) OR 9.5 (95\% CI 4.9-18.4); low back pain and chronic tension type headache OR 4.4 (95\% CI 2.1-9.0).

\section{Discussion}

In this review, we aimed to identify and describe an association between primary headache disorders and persistent low back pain. These are conditions that generate considerable morbidity globally, ${ }^{1}$ [33], but that have not been widely managed as co-morbidities. We have identified 14 studies reporting an association between primary headache disorders and persistent low back pain. Overall, there was a positive association in all studies, with odds ratios estimating the relationship between primary headache and low back pain ranged from 1.55 (95\% CI 1.13-2.11) and 8.00 (95\% CI 5.3-12.1). This appears to be a consistent finding irrespective of population studied or the study design. Although methodological quality varied, the larger epidemiological studies of Swain and
Yoon are likely to illustrate a true population association due to the large population covered [10,20]. Although, because of the extreme heterogeneity of study designs, definitions and populations studied, we cannot provide a pooled estimate the results indicate that a relationship exists between headache and low back pain. Thus, indicating reasonable grounds for further study.

We have followed the PRISMA guidance for systematic reviews during this review process [12]. The studies we identified had a large range of number of participants, a variety of methodologies, a large variety of countries, represented and participants of all ages. The total sample size represented in this review was 460435 . The review is limited by the varying definitions of chronic headache and low back pain, and in many cases, there was little explanation as to what was taken as a case definition of either headache (chronic or otherwise) or low back pain (Table 1). Some studies reported migraine specifically, but this was self-reported diagnosis, therefore may include non-migrainous headache subtypes $[15,16]$. That no studies used current diagnostic or classification criteria of headache constrains the inferences that can be drawn from the existing literature. We looked for the association between chronic headache disorders and persistent low back pain but chronicity was not always determined in the published literature, and where chronicity was clarified the definitions used were variable.

Our review may be susceptible to publication bias. Attempts at eliminating bias in observational studies have been made, including the STROBE guidelines, which provides a checklist for authors of observational studies to use when disseminating data and result [34]. This includes advice on reporting all outcome events or measures, which should therefore include negative results. However, despite a well-designed and a comprehensive search strategy in a systematic review, positive outcomes are more likely to be published than negative outcomes [35]. Since our initial scoping review indicated that data would be sparse we have included all published studies and not set a size or quality criterion to define study inclusion. Data published in languages other than English may also have been missed, however, given the consistency of our findings it is unlikely that any such studies will materially affect our overall conclusions.

We are constrained by the variable approaches to define headache disorders by the original authors. Nevertheless, we identified an important association between chronic headache and persistent low back pain in the two studies that used ICHD diagnostic criteria $[3,30]$ to define chronic headache and formally differentiate between primary headache disorders. Yoon et al. used ICHD to diagnose the primary headache disorders and chronic headache disorders; they also used our preferred 
criteria of diagnosing low back pain [10]. Ashina et al. also used ICHD criteria for headache diagnosis. ${ }^{10}$ [22], A combined approach to treating both conditions could reduce pill-burden, medication overuse, and provide a holistic treatment approach for two chronic pain syndromes.

A large-scale European study found moderate to severe chronic pain reported in 19\% of adults, notably half of these felt their pain was inadequately managed [33] A number of countries have recognised the therapeutic benefits of less location-specific pain relief in recent evidence-base back pain management guidelines (including cognitive behavioural therapies and mindfulness training) $[9,36,37]$. Treating chronic pain remains a challenge for clinicians and unfortunately unrealistic expectations of short-term pain control can lead to pharmacological over prescription (opioids in particular), and even excess interventions (including surgery or nerve blockade) [38]. Although $90 \%$ of patients who consult their general practitioner for low back pain in the UK stop consulting within 3 months, most are still experiencing low back pain and related disability 1 year after consultation [39]. This suggests that either those affected feel that there is limited help available, or that for another reason consultation is not worthwhile [40].

Understanding chronic pain is complex. There is some evidence suggesting that chronic pain conditions can be exacerbated by changes in psychological processing [41]. A review article surmised that chronic pain can lead to a vicious cycle of progressive changes in psychological well-being which are aggregated by reduced dopaminergic effects, pain sensitisation leading to worsening pain states through anti-reward and stress related neuroadapations [41]. Another low back pain study found that people exhibiting deficits in emotional awareness or difficulties in processing feelings had higher odds of experiencing low back pain [42]. There is also a genetic overlap between migraine and depressive illness [43].

Recognition of the impact that psychological processing can have on chronic pain has been recognised by the use of non-pharmacological treatments in chronic pain management. Examples include exercise therapy, and psychological therapies such as cognitive behavioural therapy [44]. Behavioural therapies have been endorsed by American Headache society, who describe chronic headache as a biopsychosocial disorder, involving not just physical disease but recognising the potential contribution of psychological processing and stressors to chronic headache symptomology [45].

In addition to considering psychosocial determinants of chronic pain processing in persistent low back pain and chronic headache, there are possible biological explanations. A previous systematic review on low back pain and other comorbidities has suggested that differences in gene expression could be implicated in the process of pain perception and signalling [46]. Similarly in migraine research, certain genetic mutations have been linked with differences in pain sensation [47]. For example, mutations in NGF (nerve growth factor) causing loss of pain perception, and TRPM8 (transient receptor potential cation channel subfamily $\mathrm{M}$ member 8) a receptor-activated non selective cation channel involved in sensing cold and possibly modulating pain sensation [47]. Monoclonal antibodies targeting calcitonin gene- related peptide (CGRP) have also been shown to have some effect in migraine prophylaxis [48] CGRP has been related to other pain mechanisms, including facet joint pain, which is a recognised cause and contributor to low back pain. A 2017 systematic review on CGRP reported that numerous studies have found an association between measured CGRP levels and pain, concluding that CGRP could be a neuromodulator in pain syndromes other than migraine [49]. Indeed, CGRP fibres have been found in degenerated human intervertebral discs sensory nerve fibres, further suggesting it may a role in nociceptive back-related pain [50]. Therefore, it is biologically plausible that the neuromodulator CGRP is involved in an association between low back pain and migraine. In this review one study in particular, Yoon et al., identified a particularly strong association between migraine and chronic low back pain [10]. This lends some support to the notion that there might be a particular association between migraine and persistent back pain mediated through a specific biological mechanism.

Headache disorders, including migraine, may be associated with chronic painful disorders other than back pain. For example, the prevalence of co-morbid migraine in people with fibromyalgia has ranged from 18\% to $36 \%$ in different studies [51]. There is a plausible link for this association through the role of central sensitisation in both disorders [51]. We are not aware of any systematic reviews quantifying the strength of the association between fibromyalgia and headache disorders. Further epidemiological work is needed to more fully explore the interrelationship between headache disorders and other painful disorders.

\section{Conclusion}

Further study should focus on the prospective and observational study of chronic headache patients and experience of persistent low back pain. In addition, study designs that examine apparent mechanisms that account for an association between persistent low back pain and primary headache disorders, in particular chronic headache would be beneficial. Such studies could lead us closer to finding concomitant management of both pain syndromes. 


\section{Clinical implications}

- Low back pain and headache are significant causes of disability worldwide.

- People with both low back pain and headache disorders may constitute a neglected patient group that could have both conditions managed in combination, rather than as separate entities.

- We identified a positive association between low back pain and headache disorders.

- A combined approach to treating both conditions could reduce pill-burden, medication overuse and provide a holistic treatment approach for the two chronic pain syndromes.

\section{Appendix}

\section{MEDLINE search strategy}

The search strategy for MEDLINE is included below.

This was adapted for the other databases.

1 Headache/(28156)

2 exp. Migraine Disorders/(28066)

3 exp. headache disorders, primary/(32171)

4 exp. Headache Disorders/(35499)

5 migraine*.mp. (36142)

6 medication overuse.mp. or exp. Prescription Drug Overuse/(1150)

7 headache.mp. or exp. Headache/(74812)

86 and 7 (942)

9 exp. Tension-Type Headache/(2081)

10 headache".mp. (82863)

111 or 2 or 3 or 4 or 5 or 8 or 9 or 10 (101688)

12 exp. Back Pain/ or exp. Low Back Pain/(37275)

13 (back pain or low back pain or backpain or low backpain or back-pain or low back-pain).mp. [mp\&\#61;title, abstract, original title, name of substance word, subject heading word, keyword heading word, protocol supplementary concept word, rare disease supplementary concept word, unique identifier, synonyms] (50956)

1412 or 13 (51111)

15 exp. Cohort Studies/or cohort.mp. (2032295)

16 exp. Case-Control Studies/or case control".mp. or case-control".mp. [mp\&\#61;title, abstract, original title, name of substance word, subject heading word, keyword heading word, protocol supplementary concept word, rare disease supplementary concept word, unique identifier, synonyms] (1024081)

17 exp. Epidemiologic Methods/or epidemiol".mp. (6107794)

18 (cross section* or cross-section*).mp. [mp\&\#61;title, abstract, original title, name of substance word, subject heading word, keyword heading word, protocol supplementary concept word, rare disease supplementary concept word, unique identifier, synonyms] (378101)

1915 or 16 or 17 or 18 (6209092)

2011 and 14 and 19 (1125)

21 limit 20 to english language (1015)

\section{Additional files}

Additional file 1: Conflicts of interests and funding of included studies. (DOCX $15 \mathrm{~kb}$ )

Additional file 2: Characteristics of excluded studies for wrong outcome. (DOCX $18 \mathrm{~kb}$ )

\section{Abbreviations}

ASSIA: Applied Social Sciences Index and Abstracts; CGRP: Calcitonin GeneRelated Peptide; Cl: Confidence Interval; GP: General Practitioner; ICHD: International Classification of Headache Disorders; LBP: Low back pain; MeSH: Medical Subject Headings; TRPM8: Transient Receptor Potential cation channel subfamily $\mathrm{M}$ member 8

\section{Acknowledgements}

We would like to thank Ms. Samantha Johnson, academic librarian at University of Warwick, for her assistance with the electronic database searches.

\section{Statistical analysis}

Statistical analysis was checked by Dr Helen Parsons (Warwick Clinical Trials Unit, Warwick Medical School, Coventry, UK) with thanks.

\section{Authors' contributions}

$A V, C E, T P, M M, M U$ made substantial contributions to the study conception and design. AV and CE made substantial contributions to the acquisition of data. All authors made substantial contributions to the analysis and interpretation of data, drafting of the article/revising it critically for important intellectual content and approved the final manuscript.

\section{Funding}

The UK Academic Foundation Programme supported AV and CE to undertake this project.

\section{Availability of data and materials}

The data used and analysed during this review are available from the corresponding author on reasonable request.

Ethics approval and consent to participate Not applicable

\section{Consent for publication}

Not applicable

\section{Competing interests}

MU was Chair of the NICE accreditation advisory committee until March 2017 for which he received a fee. He is chief investigator or co-investigator on multiple previous and current research grants from the UK National Institute for Health Research, Arthritis Research UK and is a co-investigator on grants funded by Arthritis Australia and Australian NHMRC. He has received travel expenses for speaking at conferences from the professional organisations hosting the conferences. He is a director and shareholder of Clinvivo Ltd. that provides electronic data collection for health services research. He is part of an academic partnership with Serco Ltd. related to return to work initiatives. He is a co-investigator on a study receiving support in kind from Orthospace Ltd. He is an editor of the NIHR journal series for which he receives a fee.

MSM serves on the advisory board for Allergan, St Jude Medical, Medtronic and Eli Lilly and has received payment for the development of educational presentations from Allergan, St Jude Medical, Medtronic and electroCore. 
$\mathrm{HP}$ is a co-investigator on a study receiving support in kind from Orthospace Ltd.

\section{Author details}

${ }^{1}$ University of Warwick, Coventry, UK. ${ }^{2}$ University Hospitals Coventry and Warwickshire NHS Trust, Coventry, UK. ${ }^{3}$ Centre for Epidemiology Versus Arthritis, University of Manchester, Manchester, UK. ${ }^{4}$ Royal Holloway University of London, London, UK. ${ }^{5}$ University College London (UCL) Queen Square Institute of Neurology, London, UK. ${ }^{6}$ Warwick Clinical Trials Unit, Warwick Medical School, University of Warwick, Coventry, UK.

\section{Received: 8 May 2019 Accepted: 5 July 2019}

\section{Published online: 15 July 2019}

\section{References}

1. GBD 2015 Disease and Injury Incidence and Prevalance Collaborators (2016) Global, regional, and national incidence, prevalence, and years lived with disability for 310 diseases and injuries, 1990-2015: a systematic analysis for the Global Burden of Disease Study 2015. Lancet 388:1474-547X (Electronic)

2. Hartvigsen J, Hancock MJ, Kongsted A et al (2018) What low back pain is and why we need to pay attention. Lancet 391(10137):2356-2367

3. International Headache Society (2018) The international classification of headache disorders, 3rd edition. Cephalalgia 38:1-211

4. Nichols VP, Ellard DR, Griffiths FE et al (2017) The lived experience of chronic headache: a systematic review and synthesis of the qualitative literature. BMJ Open 7(12):e019929

5. Stovner L, Hagen K, Jensen R et al (2007) The global burden of headache: a documentation of headache prevalence and disability worldwide. Cephalalgia 27(3):193-210

6. Dunn KM, Croft PR (2004) Epidemiology and natural history of low back pain. Europa Medicophysica 40:0014-2573 (Print)

7. Dionne CE, Dunn KM, Croft PR et al (2008) A consensus approach toward the standardization of back pain definitions for use in prevalence studies. Spine 33(1):95-103

8. Schwedt TJ (2014) Chronic migraine. BMJ 348:g1416

9. National Institute for Health and Care Excellence (NICE). Low back pain and sciatica in over 16s: assessment and management. United Kingdom National Institute for Clinical Excellence. 2016

10. Yoon MS, Manack A, Schramm S et al (2013) Chronic migraine and chronic tension-type headache are associated with concomitant low back pain: results of the German headache consortium study. Pain. 154:484-492

11. Dunn KM, Jordan K, Croft PR (2006) Characterizing the course of low back pain: a latent class analysis. Am J Epidemiol 163:754-761

12. LA Moher D, Tetzlaff J, Altman DG, The PRISMA Group (2009) Preferred Reporting Items for Systematic Reviews and Meta-Analyses: The PRISMA Statement. PLoS Med 6(7):e1000097

13. Wells G, Shea B, O'Connell D, et al. Newcastle-Ottawa Quality Assessment Scale, Cohort Studies. 2014

14. GA Wells, B Shea, D O'Connell, et al. The Newcastle-Ottawa scale (NOS) for assessing the quality of nonrandomised studies in meta-analyses. 2012

15. Hartvigsen J, Christensen K, Frederiksen H (2003) Back pain remains a common symptom in old age. A population-based study of 4486 Danish twins aged 70-102. Eur Spine J 12:528-534

16. Hartvigsen J, Christensen K, Frederiksen H (2004) Back and neck pain exhibit many common features in old age: a population-based study of 4,486 Danish twins 70-102 years of age. Spine. 29:576-580

17. Jones GT, Watson KD, Silman AJ et al (2003) Predictors of low back pain in British schoolchildren: a population-based prospective cohort study. Pediatrics. 111:822-828

18. Ghandour RM, Overpeck MD, Huang ZHJ et al (2004) Headache, stomachache, backache, and morning fatigue among adolescent girls in the United States - Associations with behavioral, sociodemographic, and. environmental factors. Arch Pediatr Adolesc Med 158:797-803

19. Sjolie AN (2002) Psychosocial correlates of low-back pain in adolescents. Eur Spine J 11:582-588

20. Swain MS, Henschke N, Kamper SJ et al (2014) An international survey of pain in adolescents. BMC Public Health 14:447

21. Angst F, Angst J, Ajdacic-Gross $V$ et al (2017) Epidemiology of Back pain in young and middle-aged adults: a longitudinal population cohort survey from age 27-50 years. Psychosomatics. 58:604-613
22. Ashina S, Lipton RB, Bendtsen L et al (2018) Increased pain sensitivity in migraine and tension-type headache coexistent with low back pain: a cross-sectional population study. Eur J Pain 22(5):904-914

23. Bejia I, Younes M, Jamila HB et al (2005) Prevalence and factors associated to low back pain among hospital staff. Joint Bone Spine 72:254-259

24. Bener A, Dafeeah EE, Salem MO (2015) Determinants of depression and somatisation symptoms in low back pain patients and its treatment: global burden of diseases. JPMA J Pak Med Assoc 65:473-479

25. Ahangar AA, Hossini SR, Kheirkhah F et al (2016) Associated factors of headache in an unstudied cohort of elderly subjects. Caspian J Intern Med 7: 120-125

26. Hestbaek L, Leboeuf-Yde C, Kyvik KO (2006) Is comorbidity in adolescence a predictor for adult low back pain? A prospective study of a young population. BMC Musculoskelet Disord 7:29

27. Hestbaek L, Leboeuf-Yde C, Kyvik KO et al (2004) Comorbidity with low back pain: a cross-sectional population-based survey of 12 - to 22-year-olds. Spine. 29:1483-1491 discussion 92

28. Schur EA, Afari N, Furberg $\mathrm{H}$ et al (2007) Feeling bad in more ways than one: comorbidity patterns of medically unexplained and psychiatric conditions. J Gen Intern Med 22:818-821

29. Roland M, Fairbank J (2000) The Roland-Morris disability questionnaire and the Oswestry disability questionnaire. Spine. 25:3115-3124

30. Headache Classification Subcommittee of the International Headache Society. The International Classification of Headache Disorders: 2nd edition. Cephalalgia. 2004;24(Suppl 1):9-160.

31. Yoon MS, Obermann M, Dommes P et al (2010) Chronic pain, use of mixed analgesics/opioids and medication overuse are associated with chronic daily headache: results: of german headache study. J Headache Pain 11:S63

32. Derogatis LR. SCL-90-R. Administration, Scoring and Procedures Manual-II for the R(evised) Version and Other Instruments of the Psychopathology Rating Scale Series. Clinical Psychometric Research. 1983 2nd ed. Towson

33. Breivik H, Collett B, Ventafridda V et al (2006) Survey of chronic pain in Europe: prevalence, impact on daily life, and treatment. Eur J Pain 10: 287-333

34. Vandenbroucke JP, von Elm E, Altman DG et al (2007) Strengthening the reporting of observational studies in epidemiology (STROBE): explanation and elaboration. Epidemiology 18:805-835

35. Song F, Parekh S, Hooper L et al (2010) Dissemination and publication of research findings: an updated review of related biases. Health Technol Assess 14:2046-4924 (Electronic)

36. Foster NE, Anema JR, Cherkin D et al (2018) Prevention and treatment of low back pain: evidence, challenges, and promising directions. Lancet 391 2368-2383

37. Carnes D, Homer KE, Miles CL et al (2012) Effective delivery styles and content for self-management interventions for chronic musculoskeletal pain: a systematic literature review. Clinic J Pain 28:344-354

38. Mao J (2017) Challenges of managing chronic pain. BMJ. 356

39. Croft PR, Macfarlane GJ, Papageorgiou AC et al (1998) Outcome of low back pain in general practice: a prospective study. BMJ 316:1356-1359

40. Froud $R$, Patterson $S$, Eldridge $S$, et al. A systematic review and metasynthesis of the impact of low back pain on people's lives. BMC Musculoskelet Disord. 2014; 21: 1471-2474 (Electronic)

41. Simons LE, Elman I, Borsook D (2014) Psychological processing in chronic pain: a neural systems approach. Neurosci Biobehav Rev 39:61-78

42. Mehling WE, Krause N (2005) Are difficulties perceiving and expressing emotions associated with low-back pain? The relationship between lack of emotional awareness (alexithymia) and 12-month prevalence of low-back pain in 1180 urban public transit operators. J Psychosom Res 58

43. Yang $\mathrm{Y}$, Zhao $\mathrm{H}$, Boomsma Dl, et al. Molecular genetic overlap between migraine and major depressive disorder. Eur J Hum Genet 2018; 26: 1476 5438 (Electronic)

44. Chou R, Deyo R, Friedly J et al (2017) Nonpharmacologic therapies for low Back pain: a systematic review for an American College of Physicians Clinical Practice Guideline. Ann Intern Med 166:493-495

45. Penzien DB, Taylor FR (2014) Behavioral and other nonpharmacologic treatments for headache. Headache 54:955-956

46. Ferreira PH, Beckenkamp P, Maher CG et al (2013) Nature or nurture in low back pain? Results of a systematic review of studies based on twin samples. European Journal of Pain 17:1532-2149 (Electronic)

47. Sutherland HG, LRA-Ohoo G (2017) Genetics of Migraine: Insights into the Molecular Basis of Migraine Disorders. Headache 57:1526-4610 (Electronic) 
48. Hou M, Xing H, Cai Y et al (2017) The effect and safety of monoclonal antibodies to calcitonin gene-related peptide and its receptor on migraine: a systematic review and meta-analysis. J Headache Pain 18:42

49. Schou WS, Ashina S, Amin FM et al (2017) Calcitonin gene-related peptide and pain: a systematic review. J Headache Pain 18:34

50. Ozawa T, Ohtori S, Inoue G et al (2006) The degenerated lumbar intervertebral disc is innervated primarily by peptide-containing sensory nerve fibers in humans. SPINE 31:2418-2422

51. Whealy M, Nanda S, Vincent A et al (2018) Fibromyalgia in migraine: a retrospective cohort study. J Headache Pain 19:61

\section{Publisher's Note}

Springer Nature remains neutral with regard to jurisdictional claims in published maps and institutional affiliations.

Ready to submit your research? Choose BMC and benefit from:

- fast, convenient online submission

- thorough peer review by experienced researchers in your field

- rapid publication on acceptance

- support for research data, including large and complex data types

- gold Open Access which fosters wider collaboration and increased citations

- maximum visibility for your research: over $100 \mathrm{M}$ website views per year

At BMC, research is always in progress.

Learn more biomedcentral.com/submissions 